\title{
GLIWICE RADIOCARBON DATES VI
}

\author{
MIECZYSLAW F PAZIDUR, ANNA PAZDUR, \\ and ANDRZEJ ZASTAWNY
}

Institute of Physics, Silesian Technical University, PL-44-100 Gliwice, ul Krzywoustego 2, Poland

Results presented in this date list have been obtained from Jan 1977 to Dec 1977, but some earlier measurements are also included. All calculations are based on a contemporary value equal to 0.95 of the activity of NBS oxalic acid standard and on the Libby value for the half-life of radiocarbon. Ages are reported as conventional radiocarbon dates in years before AD 1950. No corrections for ${ }^{15} \mathrm{C} /{ }^{12} \mathrm{C}$ ratio were made for measurements reported in this list. Errors quoted $( \pm 1 \sigma)$ included estimated overall standard deviations of count rates of the unknown sample, contemporary standard and background (Pazdur \& Walanus, 1979). Counting equipment and experimental procedures have been described earlier (Mościcki \& Zastawny, 1976, 1977; Pazdur et al, 1978; Pazdur \& Pazdur, 1979a). Sample descriptions are based on information provided by the submitters.

\section{SAMPLE DESCRIPTIONS}

\section{GEOLOGIC SAMPLES}

\section{A. Lake sediments}

Samples of calcareous gyttja from several profiles of lake sediments from $\mathrm{N}$ Poland were dated for paleomagnetic studies made jointly by Dept of Geophysics, Edinburgh Univ, UK, and Inst of Geophys, Pol Acad of Sci, Warsaw. All samples coll in 1976 with Mackereth corer (Mackereth, 1969) by J E Mojski, Piotr Tuchołka and Eric Hogg, subm 1977 by Zdzisław Małkowski, Inst of Geophys, Pol Acad of Sci, Warsaw.

\section{Raduńskie Lake series}

Core 2 from Raduńskie Górne Lake ( $\left.54^{\circ} 14^{\prime} \mathrm{N}, 17^{\circ} 59^{\prime} \mathrm{E}\right)$.

Gd-442A. RADG 2/I-1-5 ORG

$6620 \pm 180$

Depth from 135 to $165 \mathrm{~cm}$, organic fraction.

Gd-442B. RADG 2/I-1-5 ORG

$6600 \pm 250$

Duplicate run on 2nd counter.

Gd-454. RADG 2/I-1 CARB

$7430 \pm 190$

Depth from 145 to $155 \mathrm{~cm}$, carbonate fraction.

Gd-446. RADG 2/II-1-5 ORG

$9360 \pm 300$

Depth from 325 to $355 \mathrm{~cm}$, organic fraction.

Gd-439. RADG 2/II-1 CARB

$9470 \pm 270$

Depth from 335 to $355 \mathrm{~cm}$, carbonate fraction. 
Gd-438. RADG 2/II-2-3 CARB

Depth from 330 to $350 \mathrm{~cm}$, carbonate fraction.

Gd-449. RADG 2/III-1-3 ORG

$9940 \pm 210$

Depth from 440 to $460 \mathrm{~cm}$, organic fraction.

Gd-445. RADG 2/III-1 CARB

$9610 \pm 210$

Depth from 445 to $455 \mathrm{~cm}$, carbonate fraction.

\section{Charzykowskie Lake series}

Calcareous gyttja sediments, Core 6, from Charzykowskie Lake $\left(53^{\circ}\right.$ $\left.47^{\prime} \mathrm{N}, 17^{\circ} 28^{\prime} \mathrm{E}\right)$.

\section{Gd-451. CHAR 6/I-1-3 ORG}

$$
2850 \pm 170
$$

Depth from 140 to $160 \mathrm{~cm}$, organic fraction.

\section{Gd-475. CHAR 6/I-1-3 CARB}

$3270 \pm 160$

Depth from 140 to $160 \mathrm{~cm}$, carbonate fraction.

Gd-452. CHAR 6/II-1-3 ORG

$4870 \pm 150$

Depth from 340 to $360 \mathrm{~cm}$, organic fraction.

Gd-476. CHAR 6/II-1 CARB

Depth from 345 to $355 \mathrm{~cm}$, carbonate fraction.

$6220 \pm 120$

Gd-460. CHAR 6/III-1 CARB

$7770 \pm 220$

Depth from 495 to $505 \mathrm{~cm}$, carbonate fraction.

Gd-458. CHAR 6/IV-1 CARB

$8670 \pm 220$

Depth from 555 to $565 \mathrm{~cm}$, carbonate fraction.

Mikołajskie Lake series $\left.35^{\prime} \mathrm{E}\right)$

Calcareous gyttja, Core 2, from Mikołajskie Lake $\left(53^{\circ} 46^{\prime} \mathrm{N}, 21^{\circ}\right.$

Gd-461. MIK 2/I-1-3 ORG

$1640 \pm 140$

Depth from 215 to $235 \mathrm{~cm}$, organic fraction.

Gd-471. MIK 2/I-1.3 CARB

$1850 \pm 120$

Depth from 215 to $235 \mathrm{~cm}$, carbonate fraction.

Gd-472. MIK 2/II-1-5 ORG

$3150 \pm 130$

Depth from 435 to $465 \mathrm{~cm}$, organic fraction.

Gd-464. MIK 2/II-1-3 CARB

$2740 \pm 150$

Depth from 440 to $460 \mathrm{~cm}$, carbonate fraction.

Gd-470. MIK 2/II-4-5 CARB

$2700 \pm 130$

Depth from 435 to $440 \mathrm{~cm}$ and from 460 to $465 \mathrm{~cm}$, carbonate fraction. 
Gd-459. MIEDWIE 3/I-1-3 CARB

Calcareous gyttja from Miedwie Lake $\left(53^{\circ} 17^{\prime} \mathrm{N}, 14^{\circ} 13^{\prime} \mathrm{E}\right)$, Core 3, depth from 160 to $180 \mathrm{~cm}$, carbonate fraction.

General Comment: in all cores significant apparent age has been found. Values of apparent ages and sedimentation rates for profiles RADG2, CHAR6 and MIK2 were determined by 2-stage correction procedure described by Pazdur \& Pazdur (1979c). In 1st stage, results were smoothed by least squares line, and the approx values of apparent ages and sedimentation rates were calculated. Dates obtained by subtraction of apparent age were then corrected for long-term variations of radiocarbon, according to calibration tables of Damon et al (1973) and smoothed again by least squares line. Resulting final values of sedimentation rate, apparent age and percent initial activity of radiocarbon are listed in table 1 .

\section{TABLE 1}

Estimated values of apparent age, initial ${ }^{14} \mathrm{C}$ activity and sedimentation rate for three dated cores

\begin{tabular}{lccc}
\hline & $\begin{array}{c}\text { Raduńskie Górne } \\
\text { Lake }^{\mathrm{a}}\end{array}$ & $\begin{array}{c}\text { Charzykowskie } \\
\text { Lake }^{\mathrm{b}}\end{array}$ & $\begin{array}{c}\text { Mikołajskie } \\
\text { Lake }\end{array}$ \\
\hline Apparent age (y) & $5140 \pm 170$ & $1315 \pm 120$ & $430 \pm 100$ \\
Initial ${ }^{14}$ C concentration & 0.577 & 0.849 & 0.983 \\
Sedimentation rate (cm/100y) & $7.89 \pm 1.28$ & $6.82 \pm 0.36$ & $17.5 \pm 3.5$ \\
\hline
\end{tabular}

${ }^{a}$ values based on all dates listed.

b only dates for carbonate fraction were used in calculations.

\section{B. Other geologic samples}

\section{Gd-420. Bór na Czerwonem 1976}

Peat from base of peat bog site Bór na Czerwonem $\left(49^{\circ} 29^{\prime} \mathrm{N}, 20^{\circ}\right.$ 02' E) near Nowy Targ, depth 4.85m. Coll June 1976 by Marian Wójcikiewicz, subm by Marian Horawski, Inst Amelioration, Acad Agric, Cracow.

\section{Varanger series}

Samples coll July 1974 and subm 1976 by Alfred Jahn, Inst Geog, Wrocław Univ, Wrocław, dated for investigations of periglacial processes in Varanger peninsula $\left(72^{\circ} 40^{\prime} \mathrm{N}, 30^{\circ} 00^{\prime} \mathrm{E}\right), \mathrm{N}$ Norway.

\section{Gd-490. Varanger V-1-74}

Black peat from hill of thufur type, depth ca $50 \mathrm{~cm}$.

Gd-492. Varanger V-5-74.

Peaty fossil soil at depth from 45 to $70 \mathrm{~cm}$, overlain by gravels and turf.

\section{Gd-473. Labrador L-1-75}

Peat from palsa in permafrost region near Scheffersville, Labrador, Canada $\left(55^{\circ} 00^{\prime} \mathrm{N}, 66^{\circ} 00^{\prime} \mathrm{W}\right)$. Coll Sept 1975 and subm 1976 by Alfred Jahn. 
Gd-474. Isfiordflya S-6a-74

$2150 \pm 100$

Peat from frozen black and brown peat layer at depth $\mathrm{ca} 70 \mathrm{~cm}$ in hill of palsa type, of height ca $1 \mathrm{~m}$ and $4 \mathrm{~m}$ diam, on terrace of Isfiord, Isfiordflya, Spitsbergen $\left(78^{\circ} 10^{\prime} \mathrm{N}, 13^{\circ} 30^{\prime} \mathrm{E}\right)$. Coll June 1974 and subm 1976 by Alfred Jahn.

II. ARCHAEOLOGIC SAMPLES

\section{Milanówek-Falecin series}

Site 1 of iron foundry settlement at Milanówek-Falęcin $\left(52^{\circ} 09^{\prime} \mathrm{N}\right.$, $20^{\circ} 40^{\prime} \mathrm{E}$ ), on floodplain terrace of Rokitnica R. Excavations were conducted in 1974 and 1975 over ca $350 \mathrm{~m}^{2}$ area. 210 smelting furnaces, 2 limekilns and 1 pit dwelling were discovered. Settlement is dated to 1 st century BC/3rd century AD (Woyda, 1977). Coll 1975 and subm 1976 by Stefan Woyda, Mus Ancient Metallurgy Masovien Dist, Pruszków.

Gd-447. Milanówek-Falecin Furn 41

$2400 \pm 170$

Charcoal from base of smelting cupola furnace No. 41, Trench I/75, below large heaps of ferrugineous slag, ca $80 \mathrm{~cm}$ below present surface.

Gd-448. Milanówek-Falecin Pit 1

$2450 \pm 180$

Charcoal from layer consisting of clay and lime at base of limekiln pit No. 1, Trench I/75, ca $180 \mathrm{~cm}$ below present surface.

\section{Biskupice series}

Site 1 of iron foundry settlement, dated to 1st century BC/4th century AD, at Biskupice near Brwinów $\left(52^{\circ} 10^{\prime} \mathrm{N}, 20^{\circ} 43^{\prime} \mathrm{E}\right)$, on floodplain terrace of Zimna Woda R. Excavations started in 1976 in $7000 \mathrm{~m}^{2}$ area and resulted in discovery of 580 smelting furnaces, 3 limekilns and 10 pit dwellings (Woyda, 1977). Coll and subm 1976 by Stefan Woyda.

Gd-436. Biskupice Furn 23

$2020 \pm 155$

Charcoal from smelting furnace No. 23.

Gd-437. Biskupice Furn 56

$1940 \pm 150$

Charcoal from smelting furnace No. 56.

\section{Dobrzeń Mały series}

Charcoal from Site B of iron foundry settlement dated to period of Roman influence at Dobrzeń Mały, near Opole $\left(50^{\circ} 45^{\prime} 00^{\prime \prime} \mathrm{N}, 17^{\circ} 52^{\prime}\right.$ $45^{\prime \prime}$ E), NE of prevalley of Odra R. Samples from base of furnace pits at depth ca $80 \mathrm{~cm}$. Coll 1975 by Antoni Pawłowski, subm 1976 by Jerzy Rozpędowski, Inst Hist Architectural Arts \& Tech, Wrocław Tech Univ, Wrocław.

Gd-489. Dobrzeń Mały ob 722

$1760 \pm 70$

From object No. 722, ar 191/192.

Gd-488. Dobrzeń Mały ob 685

$1720 \pm 70$

From object No. 685. 
General Comment: compare other dates from this site: Object 19, Gd-263, $1770 \pm 140$; Object 25, Gd-298, $1660 \pm 120(\mathrm{R}, \mathrm{v} 20, \mathrm{p} 407)$.

\section{Lazy series}

Charcoal from set of primitive iron smelting furnaces, Site 6 of ordered type (Bielenin, 1977) at Lazy near Nowa Stupia $\left(50^{\circ} 85^{\prime} \mathrm{N}, 21^{\circ} 08^{\prime}\right.$ E), excavated on SE slope of Łysa Góra Mt. Lowest parts of furnace basins occur in undisturbed loess at depth 45 to $60 \mathrm{~cm}$ below present surface of arable soil. Coll and subm Aug 1976 by Kazimierz Bielenin, Archaeol Mus, Cracow. Botanical id of samples by Irena Gluza.

Gd-431. Lazy 6, Furn 76

$1790 \pm 150$

Mixed charcoal pieces (Fagus silvatica and Abies alba Mill) from furnace No. 76, left draught.

Gd-427. Lazy 6, Furn 83

Charcoal pieces of conifers (mostly Abies alba Mill) from furnace No. 83, right draught.

Gd-428. Lazy 6, Furn 27

$1730 \pm 140$

Charcoal pieces of conifers (mostly Abies alba Mill) with bark fragments, from furnace No. 27, right draught.

Gd-432. Lazy 6, Furn 58

$1895 \pm 160$

Charcoal pieces (Abies alba Mill) from furnace No. 58, right draught. General Comment (KB): 2 fragments of hand-molded ceramics were found in this site, which may be dated to period of Roman influence.

\section{GEOCHEMIICAL SAMPLES}

\section{A. Water samples}

Water samples coll by lab staff in 1976 and 1977 were measured to trace origins of water outflow from inrushes in deep coal mines of Katowice coal region. Earlier measurements from Rybnik coal region were reported in our previous lists (Mościcki \& Zastawny, 1976, Mościcki, 1977, Mościcki et al, 1978). PM (Percent Modern) is here defined as \% of 0.95 $A_{\text {ox }}$ NBS.

\begin{tabular}{|c|c|c|c|c|}
\hline Lab no. & Sample & $\begin{array}{c}\text { Depth } \\
(\mathrm{m})\end{array}$ & Colln date & PM \\
\hline Gd-411 & $\mathrm{CG} / \mathrm{S} 18 / \mathrm{S} 18 \mathrm{~A}-1$ & $\mathrm{ca} 600 \mathrm{~m}$ & Sept 1976 & $24.9 \pm 1.1$ \\
\hline $\mathrm{Gd}-426$ & $\mathrm{CG} / \mathrm{S} 18 / \mathrm{S} 18 \mathrm{~A}-2$ & $"$ & Dec 1976 & $20.6 \pm 1.1$ \\
\hline Gi-412 & $\mathrm{CG} / \mathrm{H} 2-1$ & ca $380 \mathrm{~m}$ & Sept 1976 & $25.3 \pm 0.9$ \\
\hline Gd-434 & $\mathrm{CG} / \mathrm{H}_{2}-2$ & & Dec 1976 & $21.5 \pm 1.2$ \\
\hline Gd-417 & $\mathrm{CG} / \mathrm{S}-1$ & surface & Sept 1976 & $66.3 \pm 1.4$ \\
\hline Gd-433 & $\mathrm{CG} / \mathrm{S}-2$ & " & Dec 1976 & $59.8 \pm 1.7$ \\
\hline Gd-456 & GG/PP-46-1 & ca $600 \mathrm{~m}$ & Feb 1977 & $43.2 \pm 1.1$ \\
\hline Gd-462 & GG/PP-46-2 & $"$ & May 1977 & $41.7 \pm 1.0$ \\
\hline Gd-457 & GG/GIII-1 & ca $400 \mathrm{~m}$ & Feb 1977 & $59.5 \pm 1.7$ \\
\hline Gd-467 & GG/GIII-2 & $"$ & May 1977 & $61.9 \pm 1.3$ \\
\hline Gd-466 & GG/PP-VI-2 & ca $600 \mathrm{~m}$ & May 1977 & $52.3 \pm 1.2$ \\
\hline
\end{tabular}




\section{B. Contemporary stalagmite samples}

Some recently formed stalagmites and stalactites were coll in deep coal mine in region of great water outflow at depth $400 \mathrm{~m}$, near sampling point RJ-1. Measurements of ${ }^{14} \mathrm{C}$ concentration in water bicarbonates were made from 1972 to 1975 , indicating low and stable level of ${ }^{14} \mathrm{C}$ concentration, $2.0 \pm 0.3 \%$ of modern (Mościcki, 1977). Geol characteristics of site was given by Jureczko et al (1974). Measurements of $\delta^{13} \mathrm{C}$ and $\delta^{18} \mathrm{O}$ were made by Stanisław Hałas, Inst Physics, Univ Maria Curie Skłodowska, Lublin. X-ray analysis of powdered Stg 1 sample indicates crystallographic structure of purest calcite. Results of measurements are given in table 2. Stk 1 denotes stalactite sample measured as a whole. Results for stalagmites Stg 1 and Stg 2 are listed from outer layer to central part of stalagmite.

TABLE 2

Results of ${ }^{14} \mathrm{C}$ concentration measurements in stalagmite samples. Values of $\delta^{13} \mathrm{C}$ and $\delta^{18} \mathrm{O}$ are given vs PDB standard

\begin{tabular}{llcrr}
\hline Lab no. & Sample & $\delta^{13} \mathrm{C}$ & $\delta^{18} \mathrm{O}$ & \multicolumn{1}{c}{ PM } \\
\hline Gd-292 & Stk 1 & - & - & $62.0 \pm 1.3$ \\
Gd-288 & Stg 2, outer layer & - & - & $100.3 \pm 1.7$ \\
Gd-289 & Stg 2, 1st interm layer & - & - & $85.3 \pm 1.6$ \\
Gd-290 & Stg 2, 2nd interm layer & - & - & $74.8 \pm 1.6$ \\
Gd-291 & Stg. 2, inner layer & - & - & $59.1 \pm 1.1$ \\
Gd-483 & Stg 1, outer layer & -37.02 & -24.9 & $69.5 \pm 1.5^{*}$ \\
Gd-484 & Stg 1, interm layer & -36.32 & -22.4 & $55.8 \pm 1.2^{*}$ \\
Gd-481 & Stg 1, inner layer & -35.04 & -22.0 & $48.8 \pm 1.1^{*}$ \\
\hline
\end{tabular}

* values uncorrected for $\delta^{13} \mathrm{C}$.

General Comment (MFP): evident trend in ${ }^{14} \mathrm{C}$ concentration as well as in $\delta^{13} \mathrm{C}$ and $\delta^{18} \mathrm{O}$ values indicates that ${ }^{14} \mathrm{C}$ activity of calcite samples, ca 20 to 50 times greater than ${ }^{14} \mathrm{C}$ activity of water bicarbonates, is caused by adsorption of ${ }^{14} \mathrm{C}$-enriched atmospheric $\mathrm{CO}_{2}$ on outer surface. Subsequent diffusion of ${ }^{14} \mathrm{C}$-labelled carbon atoms towards center of stalagmite and isotopic exchange with initially inactive carbon atoms occurs in $\mathrm{CaCO}_{3}$ crystals (Pazdur \& Pazdur, 1979b).

\section{Other geochemical samples}

Gd-480. Gs/090474

$134.9 \pm 1.6 \%$ PM

Atmospheric $\mathrm{CO}_{2}$ sample coll 9 April 1974 in Gliwice by Elzbieta Kostkiewicz, Inst Physics, Silesian Tech Univ, Gliwice. Comment (MFP): sample coll in urban area, industrial effect is clearly visible.

\section{Gd-493. Jawornik Polski JP40/50 $\quad 103.0 \pm 0.8 \%$ PM}

Wool, probably grown from AD 1940 to 1950, rural region of SE Poland. Coll and subm 1977 by Anna Pazdur.

Gd-494. Jawornik Polski JP76/77 $149.7 \pm 1.4 \% \mathrm{PM}$

Beeswax coll 1976/1977 in rural region of SE Poland, at Jawornik Polski village. Coll and subm by Anna Pazdur. 
REFERENCES

Bielenin, Kazimierz, 1977, Frühgeschichtliches Bergbau- und Eisenhüttenwesen in Swictokrzyskie-Gebirge, in Piekarek, Udo and Saherwala, Geraldine, eds, Eisenverhüttung vor 2000 Jahren: Archäol Forschungen in der VR Polen, Staatliche Mus Preussischer Kulturbesitz, Berlin, p 11-26.

Damon, P E, Long, Austin, and Wallick, E I, 1973, Dendrochronological calibration of the carbon-14 time scale: Internatl radiocarbon dating conf, 8th, Wellington, New Zealand, Proc, v I, p 45-59.

Jureczko, Jerzy, Mościcki, Włodzimierz, and Zastawny, Andrzej, 1974, Studies on ${ }^{14} \mathrm{C}$ activity of water from deep coal mines of Rybnik coal area in Poland: Application of natural radioactive isotopes in hydrogeology: Internatl conf, proc, Katowice, May 1974, p 270.

Mackereth, F J H, 1969, A short core sampler for sub-aquaeous deposits: Limnology Oceanography, v 14, p 142-145.

Mościcki, Włodzimicrz, $1977,{ }^{14} \mathrm{C}$ tracing in water from deep coal mines of Rybnik Coal Region and Legnica-Głogów Copper Fields, in Povinec, P, and Usacev, S, eds, Low radioactivity measurements and applications: Internatl conf, The High Tatras, Proc, p $375-378$

Mościcki, Włodzimierz, Pazdur, Anna, Pazdur, M F, and Zastawny, Andrzej, 1978, Gliwice radiocarbon dates IV: Radiocarbon, v 20, p 405-415.

Mościcki, W’odzimierz and Zastawny, Andrzej, 1976, Gliwice Gdańsk radiocarbon dates III: Radiocarbon, v 18, p 50-59.

1977 , New proportional counter assembly in Gliwice ${ }^{14} \mathrm{C}$ laboratory, in Povinec, $\mathrm{P}$ and Usacev, $\mathrm{S}$, eds, Low radioactivity measurements and applications: Internatl conf, The High Tatras, Proc, p 91-92.

Pazdur, Anna and Pazdur, M F, 1979, Skład izotopowy węgla we wspóícześnie utworzonych stalaktytach i stalagmitach (with English summary): Kwart Geol, v 23.

Pazdur, M F, and Pazdur, Anna, 1979a, Methods of sample pretreatment in Gliwice Radiocarbon Laboratory: Muzeum Archeol i Etnogr w Lodzi, Prace i Materiały, $\mathrm{v} 26$.

Pazdur, M F and Pazdur, Anna, 1979b, Radiocarbon dating of calcarcous gyttja sediments from North Polish lakes: Pol Archiv Hydrobiol, v 27.

Pazdur, M F, and Walanus, Adam, 1979, Statistical analysis of data and age calculations in Gliwice Radiocarbon Laboratory: Muzeum Archeol i Etnogr w Łodzi, Prace i Materiały, v 26.

Pazdur, M F, Walanus, Adam and Mościcki, W'odzimierz, 1978, A method of continuous examination of counting efficiency during measurements of natural radiocarbon with $\mathrm{CO}_{2}$ filled proportional counter: Nuclear Instruments Methods, v 151, p 541 547.

Woyda, Stefan, 1977, Ein Eisenverhüttungszentrum der vorrömischen Eisenzeit und der römischen Kaiserzeit, in Piekarek, Udo and Saherwala, Geraldine, eds, der Umgebung von Warschau: Eisenverhüttung vor 2000 Jahren: Archäol Forschungen in der VR Polen, Staatliche Mus Preussischer Kulturbesitz, Berlin, p 27-35.

Wójcikiewicz, Marian, ms, 1977, Stratygrafia torfowiska Bór na Czerwonem z uwzględnienicm zespớów subfosylnych oraz rozmieszczenia i zróznicowania wspóśczesnych zbiorowisk roślinnych: Ph D thesis, Acad Agriculture, Cracow. 